ISSN 1678-3921

Journal homepage: www.embrapa.br/pab

For manuscript submission and journal contents, access: www.scielo.br/pab
Alexandre Ortega Gonçalves ${ }^{(1 凶)(D)}$, Evandro Henrique Figueiredo Moura da Silva(2) (iD,

Letícia Gonçalves Gasparotto(2) (iD, Juliano Mantelatto Rosa(2) (D), Stephanie do Carmo (2) (D), Izael Martins Fattori Júnior(2) (iD and Fabio Ricardo Marin ${ }^{(2)}$ (iD)

(1) Embrapa Solos, Rua Jardim Botânico, no 1.024, Jardim Botânico, CEP 22460-000 Rio de Janeiro, RJ, Brazil.

E-mail: alexandre.ortega@embrapa.br

(2) Universidade de São Paulo, Escola Superior de Agricultura Luiz de Queiroz, Departamento de Engenharia de

Biossistemas, Avenida Pádua Dias, № 11 , Agronomia, CEP 13418-900 Piracicaba, SP, Brazil.

E-mail: ehfmsilva@gmail.com,

leticiagasparotto@usp.br,

juliano.rosa@usp.br,

stephanie2.carmo@usp.br,

izael.fattori@usp.br,

fabio.marin@usp.br

${ }^{凶}$ Corresponding author

Received

April 03, 2020

Accepted

August 31, 2020

How to cite

GONÇALVES, A.O.; SILVA, E.H.F.M da; GASPAROTTO, L.G.; ROSA, J.M.; CARMO, S. do; FATTORI JÚNIOR, I.M.; MARIN, F.R. Improving indirect measurements of the leaf area index using canopy height. Pesquisa Agropecuária Brasileira, v.55, e01894, 2020. DOI: https://doi.org/10.1590/S1678-3921. pab2020.v55.01894.

\section{Improving indirect measurements of the leaf area index using canopy height}

\begin{abstract}
The objective of this work was to evaluate the use of plant height as a calibration variable for improving indirect measurements of the leaf area index (LAI). Three experiments were conducted with different crops - corn (Zea mays), soybean (Glycine max), and sugarcane (Saccharum officinarum) -, to compare the performance of the LAI measured indirectly $\left(\mathrm{LAI}_{\text {ind }}\right)$ and corrected by the calibration variable with the LAI measured directly $\left(\mathrm{LAI}_{\mathrm{ref}}\right)$. Without the proposed correction, the $\mathrm{LAI}_{\text {ind }}$ tended to be overestimated by $20 \%$, on average, compared with the $\mathrm{LAI}_{\text {ref }}$, for the three crops. After crop height was used to adjust the $\mathrm{LAI}_{\text {ind }}$, a strong positive relationship was observed between the $\mathrm{LAI}_{\text {ref }}$ and the corrected $\mathrm{LAI}_{\text {ind }}\left(\mathrm{R}^{2}=0.96\right)$; overestimation was reduced to $4 \%$ and the mean square error decreased to $0.07 \mathrm{~m}^{2} \mathrm{~m}^{-2}$. The variable canopy height is promising for the correction of the LAI of the soybean, corn, and sugarcane crops.
\end{abstract}

Index terms: canopy architecture, corn, extinction coefficient, LAI, soybean, sugarcane.

\section{Melhoria das medições indiretas do índice de área foliar com uso da altura do dossel}

Resumo - O objetivo deste trabalho foi avaliar o uso da altura do dossel da planta como variável de ajuste para melhorar as medições indiretas do índice de área foliar (IAF). Três experimentos foram conduzidos com diferentes culturas - milho (Zea mays), soja (Glycine max) e cana-de-açúcar (Saccharum officinarum) -, para comparar o desempenho do IAF medido indiretamente $\left(\mathrm{IAF}_{\text {ind }}\right)$ e corrigido pela variável de ajuste com o IAF medido diretamente $\left(\mathrm{IAF}_{\text {ref }}\right)$. Sem a correção proposta, o $\mathrm{IAF}_{\text {ind }}$ tendeu a ser superestimado em

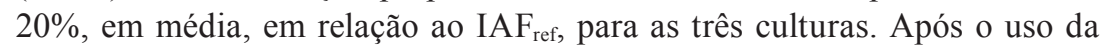
altura da colheita para ajustar o $\mathrm{IAF}_{\text {ind }}$, observaram-se fortes relações positivas entre o $\mathrm{IAF}_{\text {ref }}$ e o IAF $\mathrm{Ind}_{\text {ind }}$ corrigido $\left(\mathrm{R}^{2}=0,96\right)$; a superestimação foi reduzida para $4 \%$ e o erro médio quadrático diminuiu para $0,07 \mathrm{~m}^{2} \mathrm{~m}^{-2}$. A variável altura do dossel mostra-se promissora para correção do IAF das culturas de soja, milho e cana-de-açúcar.

Termos para indexação: arquitetura de copa, milho, coeficiente de extinção, IAF, soja, cana-de-açúcar.

\section{Introduction}

The leaf area index (LAI) is defined as the ratio of the total leaf area per unit area exploited by the crop (Miller, 1967) and is a key variable in a range of processes including gas and energy exchange, water and nutrient cycling, canopy health, and primary production (Fang et al., 
2018; Yan et al., 2019). It can be evaluated by: direct methods, such as planimeters, area integrators, and specific relationships (Chianucci \& Cutini, 2013); and indirect methods, as dry mass and electronic devices to assess the light intercepted by the canopies (Gonsamo et al., 2018; Fang et al., 2019). An accurate quantification of the LAI is, therefore, important for crop growth and development (Addai \& Alimiyawo, 2015).

Several commercial instruments may be used for the indirect measurement of the LAI, including the Accupar LP-80 Ceptometer (Meter Group, Inc., Pullman, WA, USA), LAI-2200C Plant Canopy Analyzer (LI-COR, Inc., Lincoln, NE, USA), SunScan Canopy Analysis System (Delta-T Devices Ltd, Cambridge, United Kingdom), and Demon (CSIROpedia, Canberra, Australia) (Adeboye et al., 2019).

Of these optical instruments, the LAI-2200C Plant Canopy Analyzer and its predecessor, the LAI-2000, are among the most used worldwide (Kobayashi et al., 2013; LI-COR, Inc., 2015), and their algorithms are based on the approaches proposed by Miller (1986). In the case of the LAI-2000 analyzer, the manufacturer alerts that there may be divergences in LAI estimates when the plants have a large amount of dead and/or senescent material and recommends that calibrations be made using direct LAI determinations to improve the results (Sbrissia \& Silva, 2008).

Electronic analyzers based on gap fraction or transmittance have been widely used to evaluate crops such as corn (Zea mays L.) (Ariza-Carricondo et al., 2019), sugarcane (Saccharum officinarum L.) (Lisboa et al., 2018), acid lime [Citrus latifolia (Yu.Tanaka) Tanaka] (Coelho Filho et al., 2012), and soybean [Glycine max (L.) Merr.] (Malone et al., 2002; Pierozan Junior \& Kawakami, 2013; Mbangiwa et al., 2019), as well as isolated plants of jatropha (Jatropha curcas L.) (Lena et al., 2016) and eucalyptus (Eucalyptus urophylla $\mathrm{x}$ grandis) plantations (Giunti Neto et al., 2015). However, in all these studies, the authors reported the need for calibration to improve the quality of the data gathered with those devices, but did not consider canopy height as an auxiliary variable.

Although indirect methods to estimate the LAI have already been compared in previous researches, large uncertainties still remain and the use of multiple instruments has revealed a considerable variability and uncertainty in the taken measurements
(Ariza-Carricondo et al., 2019). In some cases, it is recommended to combine the LAI-2000 instrument with another method for the correct estimation of the LAI (Ryu et al., 2010a, 2010b).

The objective of this work was to evaluate the use of plant height as a calibration variable for improving indirect measurements of the leaf area index.

\section{Materials and Methods}

Three experiments were carried out with the corn, soybean, and sugarcane crops in the experimental area of Escola Superior de Agricultura Luiz de Queiroz of Universidade de São Paulo (2241'53"S, 47³8'35"W, at $538 \mathrm{~m}$ above sea level). The climate, according to Köppen, is Cwa, described as humid subtropical with a rainy summer and a dry winter (Marin et al., 2019). All experiments were irrigated using center-pivot i-Wob UP3 sprinklers (Senninger Irrigation, Clermont, FL, USA), managed by a crop water balance based on data acquired from an automatic agrometeorological station installed in the same experimental area, in order to assure the maximum evapotranspiration rates for all the crops. Each experiment was conducted under conditions to guarantee potential yield (Ittersum et al., 2013; Fischer, 2015), without biotic or abiotic stresses (Fritsche-Neto \& Borém, 2012), and preventive actions were taken against pests and diseases. The soils were classified as Oxisols (Peters et al., 2014) in the soybean and sugarcane crop sites and as a Chromic Acrisol Nitisol (Sobenko et al., 2019) in the corn crop site. The biometric data samples consisted of: leaf length and height for corn; dry green leaf mass for sugarcane; and direct and indirect LAI determinations and canopy height measurements for all crops. The period of experimental data collection, number of observations, and a summary of the meteorological conditions are presented in Table 1.

The P-4285YH corn hybrid was sown on 5/16/2016 and harvested on 9/29/2016. The experimental design was randomized complete blocks with four replicates. Each replicate consisted of $96-\mathrm{m}^{2}$ plots, $3.2 \mathrm{~m}$ wide (four rows spaced at $0.8 \mathrm{~m}$ ) and $30 \mathrm{~m}$ long $\left(288 \mathrm{~m}^{2}\right.$ per hybrid), resulting in a population of 60,000 plants per hectare. For fertilization, $30 \mathrm{~kg} \mathrm{ha}^{-1}$ nitrogen, 90 $\mathrm{kg} \mathrm{ha}^{-1} \mathrm{P}_{2} \mathrm{O}_{5}$, and $50 \mathrm{~kg} \mathrm{ha}^{-1} \mathrm{~K}_{2} \mathrm{O}$ were applied, as well as $80 \mathrm{~kg} \mathrm{ha}^{-1}$ nitrogen topdressed. The biometric data

Pesq. agropec. bras., Brasília, v.55, e01894, 2020

DOI: 10.1590/S1678-3921.pab2020.v55.01894 
samples were taken on 7/11/2016, 7/18/2016, 8/18/2016, $8 / 25 / 2016,8 / 30 / 2016$, and 9/22/2016.

The experiment with the soybean crop consisted of a 3.0-ha field cultivated with the BRS399 RR cultivar from October 2016 to March 2017, at a row spacing of $0.45 \mathrm{~m}$ and with 18 seeds per linear meter, resulting in a plant density of 35.5 plants per square meter. The experimental design was randomized complete blocks with four replicates. Fertilization was performed by applying $196 \mathrm{~kg} \mathrm{ha}^{-1}$ single superphosphate $(18 \%$ $\mathrm{P}_{2} \mathrm{O}_{5}, 16 \% \mathrm{Ca}$, and $8 \% \mathrm{~S}$ ). Biometric data samples were collected on 11/29/2016, 12/5/2016, 12/28/2016, $1 / 5 / 2017$, and $2 / 14 / 2017$.

The RB867515 sugarcane variety was planted on $5 / 10 / 2018$, using nearly 9.7 buds per square meter, at a row spacing of $1.4 \mathrm{~m}$. The experimental design was randomized complete blocks with four replicates. From the end of August to the beginning of October 2018, the soil was prepared and received $500 \mathrm{~kg} \mathrm{ha}^{-1}$ reactive natural phosphate. Fertilization at planting consisted of $50 \mathrm{~kg} \mathrm{ha}^{-1} \mathrm{~N}, 75 \mathrm{~kg} \mathrm{ha}^{-1} \mathrm{P}_{2} \mathrm{O}_{5}$, and $75 \mathrm{~kg} \mathrm{ha}^{-1}$ $\mathrm{K}_{2} \mathrm{O}$ enriched with $0.3 \% \mathrm{~B}$ and $0.5 \% \mathrm{Zn}$. Two cover fertilizations were performed: the first in January 2019, with $177 \mathrm{~kg} \mathrm{ha}^{-1} \mathrm{~N}$ as urea and $186 \mathrm{~kg} \mathrm{ha}^{-1} \mathrm{~K}$ as potassium oxide $\left(\mathrm{K}_{2} \mathrm{O}\right)$; and the second in July 2019, with $127.5 \mathrm{~kg} \mathrm{ha}^{-1} \mathrm{~N}$ as urea. The biometric samples were taken on $1 / 23 / 2019,2 / 8 / 2019,2 / 21 / 2019,3 / 9 / 2019$, $3 / 21 / 2019,4 / 4 / 2019,4 / 15 / 2019,4 / 23 / 2019,5 / 8 / 2019$, $5 / 23 / 2019,6 / 5 / 2019,6 / 10 / 2019$, and 6/19/2019.

The samples used for the LAI measured directly $\left(\mathrm{LAI}_{\text {ref }}\right)$ and indirectly $\left(\mathrm{LAI}_{\text {ind }}\right)$ were collected on the same dates as those for biometrics. For the soybean crop, the $\mathrm{LAI}_{\text {ref }}$ was estimated with the aid of the Quant scanning and processing software, version 1.0.2 (Richter et al., 2014), used to calculate leaf area. For the corn crop, the LAI $\mathrm{I}_{\text {ref }}$ (Vieira Junior et al., 2006) was based on measuring the width and length of green leaves, multiplied by a shape correction factor of 0.7 (Marin et al., 2005). For the sugarcane crop, the LAI $\mathrm{I}_{\text {ref }}$ was obtained by the leaf disk method (Pierozan Junior \& Kawakami, 2013). For the corn and soybean crops, 5 sample plants were randomly selected among the blocks, totalizing 20 plants, for $\mathrm{LAI}_{\text {ref }}$ determinations. For the soybean and sugarcane crops, 5 sample plants 20 and 25 in total, respectively - were collected among the blocks to determine the $\mathrm{LAI}_{\text {ref }}$ by the destructive method.

For the indirect measurements of the $\mathrm{LAI}_{\mathrm{ind}}$, the LAI-2200C electronic analyzer (LI-COR, Inc., Lincoln, NE, USA), with an embedded algorithm, was used; the theoretical background of this device is fully described in Kuusk (2016). Following the manufacturer's recommendations (LI-COR, Inc., 2015), all LAI measurements were taken in the late afternoon or at sunrise to avoid the incidence of direct sunlight, at a $45^{\circ}$ angle view. It should be noted that, although not performed in this work, measurements under open-sky conditions are also allowed (Pearse et al., 2016). Besides each $\mathrm{LAI}_{\text {ind }}$, crop canopy height was measured using a ruler.

In theory, electronic retrievers work based on notions of probability, that is, the LAI-2200C analyzer measures the probability $(\mathrm{P} \Theta)$ that radiation will not be intercepted by the canopy, through the following equation (Ryu et al., 2010a; LI-COR, Inc., 2015):

$$
(\Theta)=\mathrm{e}^{(-\mathrm{G}(\Theta) \mu \mathrm{S}(\Theta))}
$$

where $G(\Theta)$ is the foliage projection fraction, $\mu$ is leaf density, and $S(\Theta)$ is the distance from the top of the canopy to soil surface. $\mathrm{S}(\Theta)$ is, therefore, a relationship between canopy height and the cosine of the angle defined between the canopy projection line and its normal (Jones, 2013).

Table 1. Period and number of leaf area index (LAI) observations, as well as a summary of the meteorological conditions during the experiment.

\begin{tabular}{lcccccc}
\hline Dataset & $\begin{array}{c}\text { Period of LAI } \\
\text { observations (mm/dd/yy) }\end{array}$ & $\begin{array}{c}\text { Number of LAI } \\
\text { observations }\end{array}$ & $\begin{array}{c}\text { Air temperature } \\
\left({ }^{\circ} \mathrm{C}\right)\end{array}$ & $\begin{array}{c}\text { Global solar } \\
\text { radiation }(\mathrm{MJ})\end{array}$ & $\begin{array}{c}\text { Rainfall } \\
(\mathrm{mm})\end{array}$ & $\begin{array}{c}\mathrm{ETo}^{(1)} \\
(\mathrm{mm})\end{array}$ \\
\hline Corn (Zea mays) & $5 / 23 / 16$ to $9 / 29 / 16$ & 7 & $18.67 \pm 3.00$ & $14.45 \pm 5.38$ & 268.7 & $313.2 \pm 1.09$ \\
Soybean (Glycine max) & $11 / 7 / 16$ to $2 / 8 / 17$ & 5 & $23.75 \pm 1.90$ & $21.08 \pm 6.28$ & 696.5 & $354.0 \pm 1.39$ \\
Sugarcane (Saccharum officinarum) & $10 / 4 / 18$ to $6 / 19 / 19$ & 13 & $23.28 \pm 2.77$ & $18.80 \pm 6.19$ & 1067.3 & $871.8 \pm 1.41$ \\
\hline
\end{tabular}

(1)Reference evapotranspiration obtained by the FAO-56 Penman-Monteith method (Allen et al., 1998). 
The $\mathrm{LAI}_{\text {ind }}$ data were statistically compared with those obtained for the $\mathrm{LAI}_{\text {ref }}$ and canopy height, using as agreement measures: Nash \& Sutcliffe's modeling efficiency (Ritter \& Muñoz-Carpena, 2013), the correlation index, the mean squared error (MSE) (Wilks, 2006), and Wilmott's index of agreement (Willmott et al., 2012).

\section{Results and Discussion}

The $\mathrm{LAI}_{\text {ind }}$ was overestimated by about $20 \%$ compared with the $\mathrm{LAI}_{\text {ref }}$ for soybean, corn, and sugarcane (Figure 1), but it expressed well the time variation of the LAI for the three crops (Table 2). Based on a theoretical model and on the gap fraction measurements from 41 sites, Kobayashi et al. (2013) reported that the effective LAI must be quantified using a second approach and that, in some cases, the LAI is overestimated up to $30 \%$ at the studied sites. Particularly for the soybean crop, the LAI-2200C analyzer was not able to estimate satisfactorily the LAI at the end-of-cycle sampling (71 days after sowing), as found by Jesus et al. (2001). As in the study of Malone et al. (2002), the results probably indicate that the estimates of LAIs with defoliation below 2.0 were likely skewed by a greater proportion of pods, stems and petioles, resulting in higher values than those obtained for the directly measured LAI. Similar results were found by Liu et al. (2008) for soybean crops, since the indirect measurement overestimated the LAI by $12.5 \%$ at 96 days after sowing. However, the $\mathrm{LAI}_{\text {ref }}$ values are consistent with those reported by Heiffig et al. (2006) for the soybean crop, by Ferreira Junior et al. (2014) and Ariza-Carricondo et al. (2019) for corn, and by Oliveira et al. (2004) for sugarcane. Likewise, the result of the present study is in agreement with that of Liu \& Pattey (2010), possibly since LAI2000 also captures other canopy tissues from below the canopy.

The $\mathrm{LAI}_{\text {ind }}$ (Figure $2 \mathrm{~A}$ ), compared with the $\mathrm{LAI}_{\text {ref, }}$ showed good accuracy for all three crops evaluated, as observed by Welles \& Norman (1991) and Jonckheere et al. (2004) when using the LAI-2000 analyzer to estimate the LAI in homogeneous canopies such as those of soybean, wheat (Triticum aestivum L.), and grass. This is probably related to the fact that, although they are not the same devices, the successors of LAI2000 use the same theoretical background, with
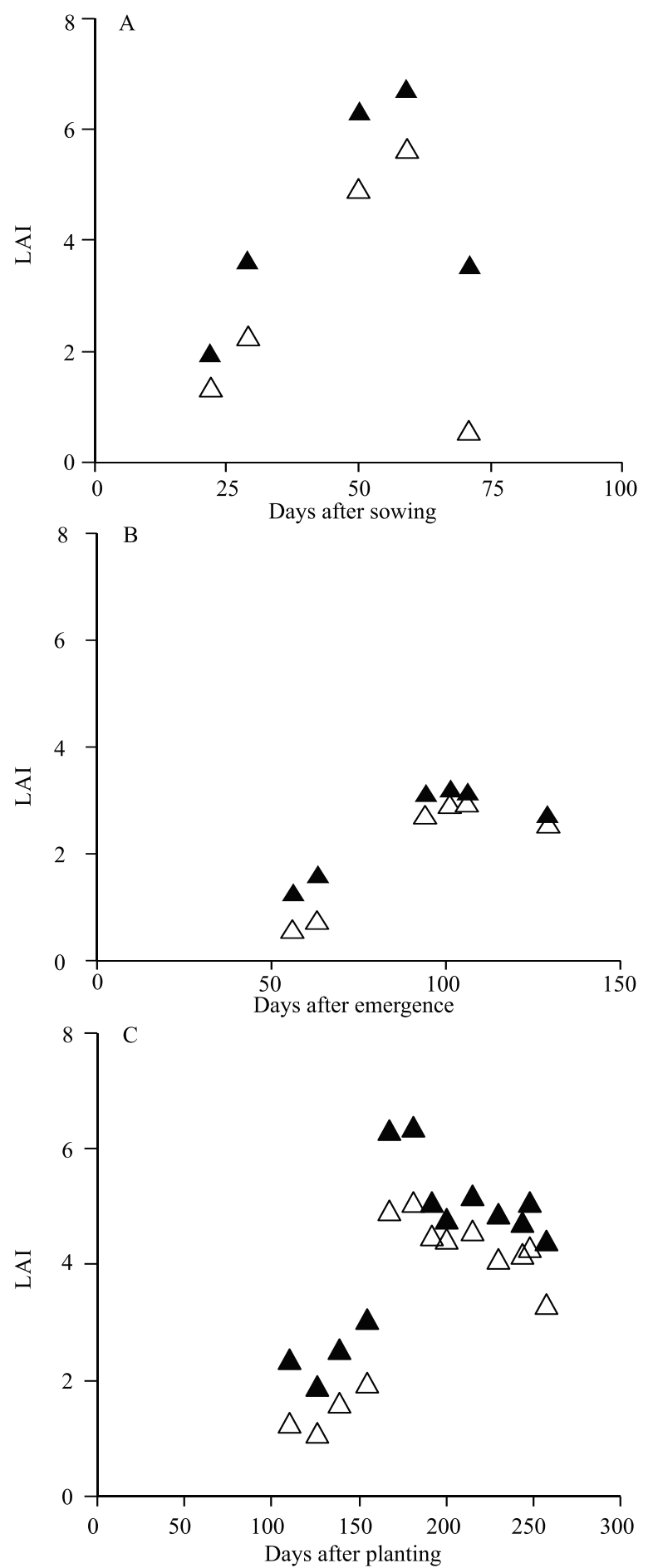

Figure 1. Leaf area index (LAI) measured directly $\left(\mathrm{LAI}_{\text {ref }}\right)$ and indirectly $\left(\mathrm{LAI}_{\text {ind }}\right)$ throughout the experiments for the: A, soybean (Glycine max); B, corn (Zea mays); and C, sugarcane (Saccharum officinarum) crops. Open and solid triangles represent $\mathrm{LAI}_{\text {ref }}$ and $\mathrm{LAI}_{\text {ind }}$, respectively. The $\mathrm{LAI}_{\text {ref }}$ and $\mathrm{LAI}_{\text {ind }}$ were measured by the destructive method and with the LAI-2200C analyzer (LI-COR, Inc., Lincoln, NE, USA), respectively. 
some improvements (Yan et al., 2019). The obtained coefficient of determination $\left(\mathrm{R}^{2}\right)$ ranged from 0.46 to 0.88 , with higher values for sugarcane and corn and a lower precision for soybean (Table 3). The lower $\mathrm{R}^{2}$ value for the soybean crop may be explained by the gap fraction highly sensitive to canopy structure, leaf distribution, and leaf plasticity (López-Lozano et al., 2007).

Although Willmott's index of agreement showed satisfactory efficiency, a way to improve the correlation

Table 2. Leaf area index measured directly $\left(\mathrm{LAI}_{\mathrm{ref}}\right)$ and indirectly $\left(\mathrm{LAI}_{\mathrm{ind}}\right)^{(1)}$ and canopy height of the soybean (Glycine max), corn (Zea mays), and sugarcane (Saccharum officinarum) crops during the experiment.

\begin{tabular}{|c|c|c|c|}
\hline $\begin{array}{l}\text { DAS or DAE } \\
\text { or } \mathrm{DAP}^{(2)}\end{array}$ & $\mathrm{LAI}_{\text {ind }}$ & $\mathrm{LAI}_{\mathrm{ref}}$ & $\begin{array}{l}\text { Canopy height } \\
\text { (m) }\end{array}$ \\
\hline & \multicolumn{3}{|c|}{ Soybean } \\
\hline 22 & 2.0 & 1.3 & 0.19 \\
\hline 29 & 3.6 & 2.3 & 0.20 \\
\hline 50 & 6.3 & 4.9 & 0.65 \\
\hline 59 & 6.7 & 5.6 & 0.77 \\
\hline 71 & 3.6 & 0.6 & 0.84 \\
\hline \multirow[t]{2}{*}{ Mean } & 4.5 & 3.0 & 0.53 \\
\hline & \multicolumn{3}{|c|}{ Corn } \\
\hline 56 & 1.3 & 0.6 & 0.29 \\
\hline 63 & 1.6 & 0.8 & 0.43 \\
\hline 94 & 3.1 & 2.7 & 1.32 \\
\hline 101 & 3.2 & 2.9 & 1.32 \\
\hline 106 & 3.2 & 2.9 & 1.45 \\
\hline 129 & 2.7 & 2.6 & 1.63 \\
\hline \multirow[t]{2}{*}{ Mean } & 2.5 & 2.1 & 1.07 \\
\hline & \multicolumn{3}{|c|}{ Sugarcane } \\
\hline 110 & 2.4 & 1.3 & 1.38 \\
\hline 126 & 1.9 & 1.1 & 1.50 \\
\hline 139 & 2.5 & 1.6 & 2.11 \\
\hline 155 & 3.1 & 2.0 & 2.45 \\
\hline 167 & 6.3 & 4.9 & 2.67 \\
\hline 181 & 6.4 & 5.1 & 2.75 \\
\hline 192 & 5.1 & 4.5 & 3.07 \\
\hline 200 & 4.8 & 4.4 & 2.80 \\
\hline 215 & 5.2 & 4.6 & 3.14 \\
\hline 230 & 4.9 & 4.1 & 3.63 \\
\hline 243 & 4.7 & 4.2 & 3.39 \\
\hline 248 & 5.1 & 4.3 & 3.55 \\
\hline 257 & 4.4 & 3.3 & 3.27 \\
\hline Mean & 4.4 & 3.5 & 2.75 \\
\hline
\end{tabular}

between the $\mathrm{LAI}_{\text {ref }}$ and $\mathrm{LAI}_{\text {ind }}$ data was still sought. In addition, the canopy height values obtained for the studied crops were considered consistent with those found by Doná et al. (2019), Shioga et al. (2015), and Oliveira et al. (2010) for similar soybean, corn, and sugarcane cultivars, respectively (Table 2); the observed peaks tended to coincide with the maximum LAI values.

After canopy height was used as a calibration variable, $\mathrm{R}^{2}$ and Willmott's index of agreement showed better performance (Figure $2 \mathrm{~B}$ ). $\mathrm{R}^{2}$ ranged from 0.95 to 0.99 , and MSE decreased considerably from 2.87 to 0.19 for soybean. In this way, there was a positive contribution to improving estimation, and all p-values were $<0.01$, except the one for soybean (Table 4). Galzerano et al. (2012) and Coêlho et al. (2014) also found a good correlation between canopy height and determinations of the LAI; however, these authors evaluated tropical grasses.

Inserting canopy height as a secondary input variable in regression reduced the error of both Willmott's index of agreement and $\mathrm{R}^{2}$; therefore, the variable contributed positively to the accuracy of the used

Table 3. Comparison between statistical tests and modeling performance with and without canopy height $(\mathrm{H})$ for the correction of the leaf area index (LAI) for the soybean (Glycine max), corn (Zea mays), and sugarcane (Saccharum officinarum) crops.

\begin{tabular}{|c|c|c|}
\hline Statistical & $\mathrm{LAI}_{\mathrm{ref}} \times \mathrm{LAI}_{\mathrm{ind}}^{(2)}$ & $\mathrm{LAI}_{\text {ref }} \mathrm{x}\left[\mathrm{LAI}_{\text {ind }} \mathrm{x} \mathrm{H}\right]$ \\
\hline & \multicolumn{2}{|c|}{ Soybean } \\
\hline $\mathrm{R}^{2}$ & 0.46 & 0.95 \\
\hline MSE & 2.87 & 0.19 \\
\hline $\mathrm{d}$ & 0.60 & 0.89 \\
\hline \multirow[t]{2}{*}{ NS } & 0.12 & 0.95 \\
\hline & \multicolumn{2}{|c|}{ Corn } \\
\hline $\mathrm{R}^{2}$ & 0.72 & 0.99 \\
\hline MSE & 1.55 & 0.03 \\
\hline d & 0.76 & 0.97 \\
\hline \multirow[t]{2}{*}{ NS } & 0.58 & 0.95 \\
\hline & \multicolumn{2}{|c|}{ Sugarcane } \\
\hline $\mathrm{R}^{2}$ & 0.88 & 0.96 \\
\hline MSE & 0.857 & 0.06 \\
\hline $\mathrm{d}$ & 0.65 & 0.97 \\
\hline NS & 0.56 & 0.96 \\
\hline
\end{tabular}

${ }^{(1)} \mathrm{R}^{2}$, coefficient of determination; MSE, mean squared error; $d$, Willmott's index of agreement; and NS, Nash-Sutcliffe's index of agreement. (2) $\mathrm{LAI}_{\text {ref }}, \mathrm{LAI}$ obtained directly by the destructive method; and $\mathrm{LAI}_{\text {ind }}, \mathrm{LAI}$ obtained indirectly with the LAI-2200C analyzer (LI-COR, Inc., Lincoln, NE, USA). 
method (Table 3). Although canopy height improved the verified correlation, it is possible that other factors influence LAI-2200C measurements, mainly in the
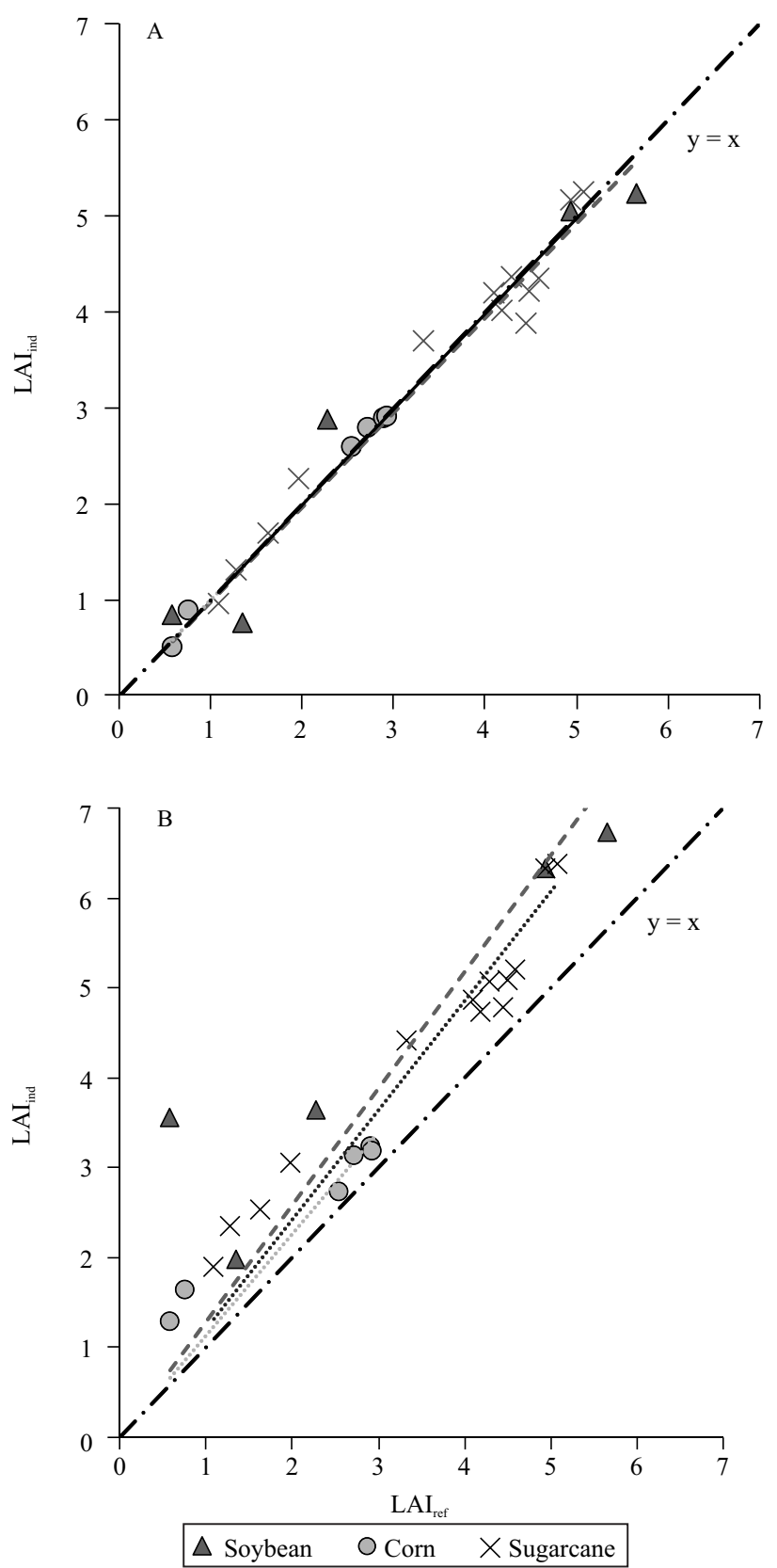

Figure 2. Scatter plot of the leaf area index measured directly $\left(\mathrm{LAI}_{\mathrm{ref}}\right)$ and indirectly $\left(\mathrm{LAI}_{\text {ind }}\right)$ throughout the experiments for the soybean (Glycine max), corn (Zea mays), and sugarcane (Saccharum officinarum) crops (A) and scatter plot of the leaf area index corrected by canopy height (B). The $\mathrm{LAI}_{\text {ref }}$ and $\mathrm{LAI}_{\text {ind }}$ were measured by the destructive method and with the LAI-2200C analyzer (LICOR, Inc., Lincoln, NE, USA), respectively. crop reproductive stage due to a logical relationship, which implies that other plant structures, such as stems and pods, are considered as leaf area (Malone et al., 2002). This process seems to have occurred for the soybean cultivar evaluated in the present work (Figure 2 B). Welles \& Norman (1991) reported another source of uncertainty in the theory behind analyzers, highlighting that the electronic indirect method fails to distinguish senescent or dead tissue from living tissue, increasing the discrepancy in the LAI readings, as in the case of the soybean crop. To improve measurements, Nilson (1971) suggests relating clumping to the size of vegetative elements and to the distance between them. Kucharik et al. (1998) compared the variation of this parameter in a homogeneous canopy and found that the LAI, under these conditions, only varies as a function of canopy height.

Canopy height proves to be a promising calibration variable for use in the corn and sugarcane crops. One of the reasons is that, since the LAI can be determined throughout the crop cycle by indirect measurements, more reliable data can be obtained. In both crops, correcting by canopy height resulted in a more accurate LAI because these plants have a higher proportion of leaves than other structures, when compared with soybean (Argenta et al., 2001).

Table 4. Linear regression coefficients between the leaf area index measured directly $\left(\mathrm{LAI}_{\mathrm{ref}}\right)$ and indirectly $\left(\mathrm{LAI}_{\mathrm{ind}}\right)^{(1)}$ and canopy height $(\mathrm{H})$, as input variables, for the soybean (Glycine max), corn (Zea mays), and sugarcane (Saccharum officinarum) crops throughout the experiments.

\begin{tabular}{lccc}
\hline Variables & Coefficient & P-value \\
\hline \multicolumn{3}{c}{ Soybean } \\
Intersection & -1.2662413 & 0.271 \\
$\mathrm{LAI}_{\text {ind }}$ & 1.30994127 & 0.027 \\
$\mathrm{H}$ & -0.030408 & 0.167 \\
\hline \multicolumn{3}{c}{ Corn } \\
Intersection & -0.8797169 & & 0.014 \\
$\mathrm{LAI}_{\text {ind }}$ & 0.94336531 & 0.006 \\
$\mathrm{H}$ & 0.00541574 & 0.077 \\
\hline & \multicolumn{3}{c}{ Sugarcane } \\
Intersection & -1.1741805 & 0.005 \\
$\mathrm{LAI}_{\text {ind }}$ & 0.87195609 & $<0.01$ \\
$\mathrm{H}$ & 0.00311855 & 0.090 \\
\hline
\end{tabular}

(1) Measured directly by the destructive method and indirectly with the LAI-2200C analyzer (LI-COR, Inc., Lincoln, NE, USA). 


\section{Conclusions}

1. The values of the leaf area index (LAI) estimated by the LAI-2200C electronic device are overestimated for the soybean (Glycine max), corn (Zea mays), and sugarcane (Saccharum officinarum) crops.

2. Canopy height as a calibration variable can correct indirect LAI measurements and improve agreement with direct LAI measurements.

\section{Acknowledgments}

To Conselho Nacional de Desenvolvimento Científico e Tecnológico (CNPq), for grants (process numbers 301424/2015-2, 401662/2016-0, and 425174/2018-2); to Fundação de Amparo à Pesquisa do Estado de São Paulo (Fapesp), for grants (process numbers 2017/20925-0 and 2017/50445-0); and to Empresa Brasileira de Pesquisa Agropecuária (Embrapa) and to Coordenação de Aperfeiçoamento de Pessoal de Nível Superior (Capes), for support.

\section{References}

ADDAI, I.K.; ALIMIYAWO, M. Graphical determination of leaf area index and its relationship with growth and yield parameters of sorghum (Sorghum bicolor L. Moench) as affected by fertilizer application. Journal of Agronomy, v.14, p.272-278, 2015. DOI: https://doi.org/10.3923/ja.2015.272.278.

ADEBOYE, O.B.; ADEBOYE, A.P.; ANDERO, O.S.; FALANA, O.B. Evaluation of AccuPAR LP 80 in estimating leaf area index of soybeans canopy in Ile-Ife, Nigeria. Agricultural Research, v.8, p.297-308, 2019. DOI: https://doi.org/10.1007/s40003-0180371-1.

ALLEN, R.G.; PEREIRA, L.S.; RAES, D.; SMITH, M. Crop evapotranspiration: guidelines for computing crop requirements. Rome: FAO, 1998. (FAO Irrigation and Drainage Paper, 56). DOI: https://doi.org/10.1016/j.eja.2010.12.001.

ARGENTA, G.; SILVA, P.R.F. da; SANGOI, L. Arranjo de plantas em milho: análise do estado-da-arte. Ciência Rural, v.31, p.1075-1084, 2001. DOI: https://doi.org/10.1590/S010384782001000600027.

ARIZA-CARRICONDO, C.; MAURO, F. DI; BEECK, M.O. de; ROLAND, M.; GIELEN, B.; VITALE, D.; CEULEMANS, R.; PAPALE, D. A comparison of different methods for assessing leaf area index in four canopy types. Central European Forestry Journal, v.65, p.67-80, 2019. DOI: https://doi.org/10.2478/forj2019-0011.

CHIANUCCI, F.; CUTINI, A. Estimation of canopy properties in deciduous forests with digital hemispherical and cover photography. Agricultural and Forest Meteorology, v.168, p.130139, 2013. DOI: https://doi.org/10.1016/j.agrformet.2012.09.002.
COELHO FILHO, M.A.; VILLA-NOVA, N.A.; ANGELOCCI, L.R.; MARIN, F.R.; RIGHI, C.A. Método para estimativa do IAF de árvores isoladas ou de plantações com dossel fechado. Revista Brasileira de Engenharia Agrícola e Ambiental, v.16, p.529-538, 2012. DOI: https://doi.org/10.1590/S1415-43662012000500009.

COÊLHO, J.J.; DUBEUX JR, J.C.B.; SANTOS, E.R.S.; LEÃO NETO, J.M.C.; CUNHA, M.V. da; SANTOS, M.V.F. dos; MELLO, A.C.L. de; LIRA, M. de A. Canopy height and its relationship with leaf area index and light interception in tropical grasses. Tropical Grasslands - Forrajes Tropicales, v.2, p.31-32, 2014. DOI: https://doi.org/10.17138/TGFT(2)31-32.

DONÁ, S.; KANTHACK, R.A.D.; CAÇÃO, M.M. de F.R.; SANTOS, G.X.L.dos; CORDEIRO-JUNIOR,P.S.;NAKAYAMA, F.T.; FINOTO, E.L.; LEÃO, P.C. da L. Desempenho agronômico de cultivares de soja no Vale do Paranapanema, Safras 2017/18 e 2018/19. Nucleus, p.63-76, 2019. Edição especial. DOI: https://doi.org/10.3738/1982.2278.3626.

FANG, H.; BARET, F.; PLUMMER, S.; SCHAEPMAN-STRUB, G. An overview of global leaf area index (LAI): methods, products, validation, and applications. Reviews of Geophysics, v.57, p.739799, 2019. DOI: https://doi.org/10.1029/2018RG000608.

FANG, H.; YE, Y.; LIU, W.; WEI, S.; MA, L. Continuous estimation of canopy leaf area index (LAI) and clumping index over broadleaf crop fields: an investigation of the PASTIS-57 instrument and smartphone applications. Agricultural and Forest Meteorology, v.253-254, p.48-61, 2018. DOI: https://doi.org/10.1016/J.AGRFORMET.2018.02.003.

FERREIRA JUNIOR, R.A.; SOUZA, J.L. de; TEODORO, I.; LYRA, G.B.; SOUZA, R.C. de; ARAÚJO NETO, R.A. de. Eficiência do uso da radiação em cultivos de milho em Alagoas. Revista Brasileira de Engenharia Agrícola e Ambiental, v.18, p.322-328, 2014. DOI: https://doi.org/10.1590/S141543662014000300012.

FISCHER, R.A. Definitions and determination of crop yield, yield gaps, and of rates of change. Field Crops Research, v.182, p.9-18, 2015. DOI: https://doi.org/10.1016/j.fcr.2014.12.006.

FRITSCHE-NETO, R.; BORÉM, A. (Ed.). Plant breeding for biotic stress resistance. Heidelberg: Springer, 2012. DOI: https://doi.org/10.1007/978-3-642-33087-2

GALZERANO, L.; MALHEIROS, E.B.; MORGADO, E. da S.; RUGGIERI, A.C. Interceptação de luz e índice de área foliar em relação a altura do dossel de gramíneas forrageiras. Nucleus Animalium, v.4, p.11-18, 2012. DOI: https://doi.org/10.3738/ NA.V4I2.742.

GIUNTI NETO, C.J.; HAKAMADA, R.E.; OTTO, M.S.G.; SILVA, S.R.; STAPE, J.L. Calibração de dois métodos indiretos para estimativa do índice de área foliar em plantações de Eucalyptus. Scientia Forestalis, v.43, p.919-930, 2015. DOI: https://doi.org/10.18671/scifor.v43n108.16.

GONSAMO, A.; WALTER, J.-M.; CHEN, J.M.; PELLIKKA, P.; SCHLEPPI, P. A robust leaf area index algorithm accounting for the expected errors in gap fraction observations. Agricultural and Forest Meteorology, v.248, p.197-204, 2018. DOI: https://doi.org/10.1016/J.AGRFORMET.2017.09.024.

HEIFFIG, L.S.; CÂMARA, G.M. de S.; MARQUES, L.A.; PEDROSO, D.B.; PIEDADE, S.M. de S. Fechamento e índice de 
área foliar da cultura da soja em diferentes arranjos espaciais. Bragantia, v.65, p.285-295, 2006. DOI: https://doi.org/10.1590/ S0006-87052006000200010.

ITTERSUM, M.K. van; CASSMAN, K.G.; GRASSINI, P.; WOLF, J.; TITTONELL, P.; HOCHMAN, Z. Yield gap analysis with local to global relevance - a review. Field Crops Research, v.143, p.4-17, 2013. DOI: https://doi.org/10.1016/j.fcr.2012.09.009.

JESUS, W.C. de; VALE, F.X.R. do; COELHO, R.R.; COSTA, L.C. Comparison of two methods for estimating leaf area index on common bean. Agronomy Journal, v.93, p.989-991, 2001. DOI: https://doi.org/10.2134/agronj2001.935989x.

JONCKHEERE, I.; FLECK, S.; NACKAERTS, K.; MUYS, B.; COPPIN, P.; WEISS, M.; BARET, F. Review of methods for in situ leaf area index determination. Part I. Theories, sensors and hemispherical photography. Agricultural and Forest Meteorology, v.121, p.19-35, 2004. DOI: https://doi.org/10.1016/j. agrformet.2003.08.027.

JONES, H.G. Plants and microclimate: a quantitative approach to environmental plant physiology. $3^{\text {rd }}$ ed. Cambridge: Cambridge University Press, 2013. DOI: https://doi.org/10.1017/ CBO9780511845727.

KOBAYASHI, H.; RYU, Y.; BALDOCCHI, D.D.; WELLES, J.M.; NORMAN, J.M. On the correct estimation of gap fraction: how to remove scattered radiation in gap fraction measurements? Agricultural and Forest Meteorology, v.174-175, p.170-183, 2013. DOI: https://doi.org/10.1016/J.AGRFORMET.2013.02.013.

KUCHARIK, C.J.; NORMAN, J.M.; GOWER, S.T. Measurements of leaf orientation, light distribution and sunlit leaf area in a boreal aspen forest. Agricultural and Forest Meteorology, v.91, p.127148, 1998. DOI: https://doi.org/10.1016/S0168-1923(98)00058-6.

KUUSK, A. Specular reflection in the signal of LAI-2000 plant canopy analyzer. Agricultural and Forest Meteorology, v.221, p.242-247, 2016. DOI: https://doi.org/10.1016/j. agrformet.2016.02.015.

LENA, B.P.; FOLEGATTI, M.V.; FRANCISCO, J.P.; SANTOS, O.N.A.; ANDRADE, I.P.S. Performance of LAI2200 Plant Canopy Analyzer on leaf area index of jatropha nut estimation. Journal of Agronomy, v.15, p.191-197, 2016. DOI: https://doi.org/10.3923/ja.2016.191.197.

LI-COR, INC. LAI-2200C Plant Canopy Analyzer: instruction manual. Lincoln, [2015]. 258p.

LISBOA, I.P.; CHERUBIN, M.R.; LIMA, R.P.; CERRI, C.C.; SATIRO, L.S.; WIENHOLD, B.J.; SCHMER, M.R.; JIN, V.L.; CERRI, C.E.P. Sugarcane straw removal effects on plant growth and stalk yield. Industrial Crops and Products, v.111, p.794806, 2018. DOI: https://doi.org/10.1016/j.indcrop.2017.11.049.

LIU, G.; XIE, Y.; GAO, X.-F.; DUAN, X.-W. Application of SunScan canopy analysis system in measuring leaf area index of soybean. Chinese Journal of Ecology, v.27, p.862-866, 2008.

LIU, J.; PATTEY, E. Retrieval of leaf area index from top-ofcanopy digital photography over agricultural crops. Agricultural and Forest Meteorology, v.150, p.1485-1490, 2010. DOI: https://doi.org/10.1016/j.agrformet.2010.08.002.

LÓPEZ-LOZANO, R.; BARET, F.; CHELLE, M.; ROCHDI, N.; ESPAÑA, M. Sensitivity of gap fraction to maize architectural characteristics based on 4D model simulations. Agricultural and Forest Meteorology, v.143, p.217-229, 2007. DOI: https://doi.org/10.1016/j.agrformet.2006.12.005.

MALONE, S.; HERBERT, D.A.; HOLSHOUSER, D.L. Evaluation of the LAI-2000 Plant Canopy Analyzer to estimate leaf area in manually defoliated soybean. Agronomy Journal, v.94, p.10121019, 2002. DOI: https://doi.org/10.2134/agronj2002.1012.

MARIN, F.R.; ANGELOCCI, L.R.; NASSIF, D.S.P.; VIANNA, M.S.; PILAU, F.G.; SILVA, E.H.F.M. da; SOBENKO, L.R.; GONÇALVES, A.O.; PEREIRA, R.A.A.; CARVALHO, K.S. Revisiting the crop coefficient - reference evapotranspiration procedure for improving irrigation management. Theoretical and Applied Climatology, v.138, p.1785-1793, 2019. DOI: https://doi.org/10.1007/s00704-019-02940-7.

MARIN, F.R.; ANGELOCCI, L.R.; RIGHI, E.Z.; SENTELHAS, P.C. Evapotranspiration and irrigation requirements of a coffee plantation in Southern Brazil. Experimental Agriculture, v.41, p.187-197, 2005. DOI: https://doi.org/10.1017/S0014479704002480.

MBANGIWA, N.C.; SAVAGE, M.J.; MABHAUDHI, T. Modelling and measurement of water productivity and total evaporation in a dryland soybean crop. Agricultural and Forest Meteorology, v.266-267, p.65-72, 2019. DOI: https://doi.org/10.1016/j.agrformet.2018.12.005.

MILLER, J.B. A formula for average foliage density. Australian Journal of Botany, v.15, p.141-144, 1967. DOI: https://doi.org/10.1071/BT9670141.

MILLER, J.B. The foliage density equation revisited. Journal of the Australian Mathematical Society. Series B. Applied Mathematics, v.27, p.387-401, 1986. DOI: https://doi.org/10.1017/ S0334270000005038.

NILSON, T. A theoretical analysis of the frequency of gaps in plant stands. Agricultural Meteorology, v.8, p.25-38, 1971. DOI: https://doi.org/10.1016/0002-1571(71)90092-6.

OLIVEIRA, E.C.A. de; OLIVEIRA, R.I. de; ANDRADE, B.M.T. de; FREIRE, F.J.; LIRA JÚNIOR, M.A.; MACHADO, P.R. Crescimento e acúmulo de matéria seca em variedades de canade-açúcar cultivadas sob irrigação plena. Revista Brasileira de Engenharia Agrícola e Ambiental, v.14, p.951-960, 2010. DOI: https://doi.org/10.1590/S1415-43662010000900007.

OLIVEIRA, R.A. de; DAROS, E.; ZAMBON, J.L.C.; WEBER, H.; IDO, O.T.; ZUFFELLATO-RIBAS, K.C.; KOEHLER, H.S.; SILVA, D.K.T. da. Crescimento e desenvolvimento de três cultivares de cana-de-açúcar, em cana-planta, no Estado do Paraná. Scientia Agraria, v.5, p.87-94, 2004. DOI: https://doi.org/10.5380/rsa.v5i1.1102.

PEARSE, G.D.; WATT, M.S.; MORGENROTH, J. Comparison of optical LAI measurements under diffuse and clear skies after correcting for scattered radiation. Agricultural and Forest Meteorology, v.221, p.61-70, 2016. DOI: https://doi.org/10.1016/J. AGRFORMET.2016.02.001.

PETERS, L.P.; CARVALHO, G.; MARTINS, P.F.; DOURADO, M.N.; VILHENA, M.B.; PILEGGI, M.; AZEVEDO, R.A. Differential responses of the antioxidant system of ametryn and clomazone tolerant bacteria. PLoS ONE, v.9, e112271, 2014. DOI: https://doi.org/10.1371/journal.pone.0112271.

PIEROZAN JUNIOR, C.; KAWAKAMI, J. Efficiency of the leaf disc method for estimating the leaf area index of soybean plants.

Pesq. agropec. bras., Brasília, v.55, e01894, 2020

DOI: 10.1590/S1678-3921.pab2020.v55.01894 
Acta Scientiarum. Agronomy, v.35, p.487-493, 2013. DOI: https://doi.org/10.4025/actasciagron.v35i4.16290.

RICHTER, G.L.; ZANON, A.J.; STRECK, N.A.; GUEDES, J.V.C.; KRÄULICH, B.; ROCHA, T.S.M. da; WINCK, J.E.M.; CERA, J.C. Estimativa da área de folhas de cultivares antigas e modernas de soja por método não destrutivo. Bragantia, v.73, p.416-425, 2014. DOI: https://doi.org/10.1590/1678-4499.0179.

RITTER, A.; MUÑOZ-CARPENA, R. Performance evaluation of hydrological models: Statistical significance for reducing subjectivity in goodness-of-fit assessments. Journal of Hydrology, v.480, p.33-45, 2013. DOI: https://doi.org/10.1016/j. jhydrol.2012.12.004.

RYU, Y.; NILSON, T.; KOBAYASHI, H.; SONNENTAG, O.; LAW, B.E.; BALDOCCHI, D.D. On the correct estimation of effective leaf area index: does it reveal information on clumping effects? Agricultural and Forest Meteorology, v.150, p.463-472, 2010a. DOI: https://doi.org/10.1016/j.agrformet.2010.01.009.

RYU, Y.; SONNENTAG, O.; NILSON, T.; VARGAS, R.; KOBAYASHI, H.; WENK, R.; BALDOCCHI, D.D. How to quantify tree leaf area index in an open savanna ecosystem: a multi-instrument and multi-model approach. Agricultural and Forest Meteorology, v.150, p.63-76, 2010b. DOI: https://doi.org/10.1016/j.agrformet.2009.08.007.

SBRISSIA, A.F.; SILVA, S.C. da. Comparação de três métodos para estimativa do índice de área foliar em pastos de capimmarandu sob lotação contínua. Revista Brasileira de Zootecnia, v.37, p.212-220, 2008. DOI: https://doi.org/10.1590/S151635982008000200006 .

SHIOGA, P.S.; GERAGE, A.C.; ARAÚJO, P.M. de; BIANCO, R.; CUSTÓDIO, A.A. de P. Avaliação estadual de cultivares de milho segunda safra 2015. Londrina: IAPAR, 2015. 101p. (IAPAR. Boletim técnico, 86).

SOBENKO, L.R.; SOUZA, T.T.; GONÇALVES, A.O.; BIANCHINI, V.J.M.; SILVA, E.H.F.M.; SOUZA, L.T.; MARIN, F.R. Irrigation requirements are lower than those usually prescribed for a maize crop in Southern Brazil. Experimental Agriculture, v.55, p.662-671, 2019. DOI: https://doi.org/10.1017/ S0014479718000339.

VIEIRA JUNIOR, P.A.; DOURADO NETO, D.; BERNARDES, M.S.; FANCELLI, A.L.; MANFRON, P.A.; MARTIN, T.N. Metodologia para estimativa da área foliar de genótipos de milho. Revista Brasileira de Milho e Sorgo, v.5, p.182-191, 2006. DOI: https://doi.org/10.18512/1980-6477/rbms.v5n2p182-191.

WELLES, J.M.; NORMAN, J.M. Instrument for indirect measurement of canopy architecture. Agronomy Journal, v.83, p.818-825, 1991. DOI: https://doi.org/10.2134/agronj1991.0002196 2008300050009x.

WILKS, D.S. Statistical methods in the atmospheric sciences. $2^{\text {nd }}$ ed. Amsterdam: Elsevier, 2006. 627p. (International Geophysics Series, v.91).

WILLMOTT, C.J.; ROBESON, S.M.; MATSUURA, K. A refined index of model performance. International Journal of Climatology, v.32, p.2088-2094, 2012. DOI: https://doi.org/10.1002/joc.2419.

YAN, G.; HU, R.; LUO, J.; WEISS, M.; JIANG, H.; MU, X.; XIE, D.; ZHANG, W. Review of indirect optical measurements of leaf area index: recent advances, challenges, and perspectives. Agricultural and Forest Meteorology, v.265, p.390-411, 2019. DOI: https://doi.org/10.1016/j.agrformet.2018.11.033. 